Gáspár Csaba ${ }^{1}-$ Kasik Lászlón

${ }^{1}$ SZTE BTK Nevelésudományi Doktori Iskola

${ }^{2}$ SZTE BTK Neveléstudományi Intézet, Neveléselmélet Tanszék, SZTE Szociális Kompetencia Kutatócsoport

\title{
A szociálisprobléma-megoldás, az empátia és a szorongás kapcsolata serdülők körében
}

Személyközi problémáink módja és sikeressége nagymértékben meghatározza társas jóllétünket, hatással van tanulmányi-szakmai elómenetelünkre és pszichés egészségünkre (Chang, D'Zurilla és

Sanna, 2004). A problémamegoldás sikeressége számos személyiségbeli és környezeti tényezótól függ, melyek közül - az eddigi hazai (pl. Kasik, 2015) és nemzetközi (pl. Chang és mtsai, 2004) vizsgálatok alapján - már serdülókorban is jelentốs a szerepe az empátia és a szorongás egyes jellemzóinek, vagyis ezek fejlettsége meghatározó a problémamegoldás alakulásában és fordítva: mind a szorongás, mind az empátia függ a problémák megoldásának

hatékonyságától. A tanulmányban ismertetett vizsgálat során serdülók (12-19 évesek) körében tártuk fel e három terület néhány részterületének kapcsolatrendszerét keresztmetszeti és longitudinális vizsgálat keretében. A vizsgálatok alapján az életkorral fokozatosan erósödik a kapcsolat a problémamegoldás pozitív orientációja és az empátia egyik kognitív részterülete, a nézópontfelvétel/-váltás között.

A negatív orientáció és az elkerülés, illetve az impulzivitás az empátia másik összetevójével, a személyes distresszel mutat egyre szorosabb kapcsolatot. A negativ orientációra nagy hatással bir mindegyik életkori csoportban a vonásszorongás. A mindennapi pedagógiai gyakorlatban, valamint a jövóbeni kutatási-fejlesztési célok megfogalmazásakor és megvalósításakor egyaránt hasznosak. lehetnek a feltârt összefüggések.

\section{Szociálisprobléma-megoldás, empátia, szorongás - elméleti háttér}

\section{Szociálisprobléma-megoldás}

A szociálisprobléma-megoldó gondolkodás és viselkedés (szociálisprobléma-megoldás) jellemzőinek vizsgálatát a 20. század második felében zajló kognitív pszichológiai kutatások alapozták meg. Ezen vizsgálatok eredményei arra hívták fel a figyelmet, hogy a különböző kognitív folyamatok alapvető szerepet játszanak a társas viselkedés tervezésében, kivitelezésében és értékelésében (Coy, Speltz, De Klyen és

* Kasik László a tanulmány megírása alatt Bolyai János Kutatási Ösztöndíjban részesült. 
Jones, 2001; Chang, D'Zurilla és Sanna, 2004; Mott és Krane, 2006). A vizsgálatok legfontosabb kérdései közé tartozott, hogy mit tud és mit gondol az egyén saját és társai viselkedéséről, különböző társas szituációkról, és ezeket az információkat hogyan alkalmazza viselkedésének tervezése és kivitelezése során. A másik fontos kérdés az volt, melyek azok a pszichikus komponensek és miként müködnek, amelyek e folyamat során meghatározó szerepet töltenek be (pl. D’Zurilla és Goldfried, 1971). Az 1980-as évek elején végzett vizsgálatok alapján előtérbe kerültek olyan eredmények, melyek szerint az érzelmek és gondolkodás között szoros kapcsolat áll fenn. Az érzelmeink feldolgozása, jelenléte befolyásolják, sőt szabályozzák az információ feldolgozásának mozzanatait, így viselkedésünket is. Nem csak érzelmi, hanem környezeti tényezők is nagy hatással vannak a gondolkodás, az egyén viselkedésének alakulására.

D’Zurilla és munkatársai (2002) a szociálisprobléma-megoldó gondolkodás négy részfolyamatát különítették el, melyek a következőek: (1) a probléma definiálása ('definition and formulation'); (2) alternatív megoldási módok keresése ('alternative solutions'); (3) a legalkalmasabb megoldás kiválasztása, döntés a megoldásról ('decision making'); (4) kivitelezés és annak értékelése ('solution implementation and verification') (Kasik, 2010, 2015). A probléma felismerésében, azonosításában nagy szerepet játszanak személyiségünk különböző tulajdonságai. A probléma felismerése során fontos az észlelési képesség és más kognitív komponens (pl. nézőpont-átvétel) müködése is, együttesen a probléma és a másik perspektívájának megértését segítik (Channon és Crawford, 2010). A problémaorientáció szoros összefüggést mutat néhány érzelmi és szociális képességgel (pl. érzelemfelismerés, együttmüködés). A megoldási szakasz utolsó részfolyamatában, a kivitelezés során az érdekérvényesítés módja is meghatározó (Kasik, 2010).

D’Zurilla és Maydeu-Olivares (1996) szerint az orientációs szakasz két fö dimenzió (pozitív és negatív) mentén szabályozza a gondolkodást. D’Zurilla, Nezu és Maydeu-Olivares (2002) a problémamegoldás orientációs része mellett, azzal egyetértve, a megoldás három főbb stílusát különítették el. A pozitív és a negatív orientáció mellett elkülönítették a racionális, az impulzív és az elkerülő stílust. A pozitív orientáció a problémához való pozitív, bizakodó viszonyulást (a probléma megoldható, meg tudja oldani, célként értelmezi, pl. „Meg tudom oldani a problémáimat.”), a negatív orientáció a problémához és a megoldási folyamathoz való negatív viszonyulást, a megoldáshoz társuló negatív érzelmek kifejezését (pl. „Túl sokat aggódom a problémáim miatt.”) mutatja. A racionalitás a tényeken alapuló, a tények kapcsolatait, az ok-okozati összefüggéseket figyelembe vevő döntést és problémamegoldást jelenti (pl. „Megpróbálok minél több megoldási lehetőséget keresni."). Az impulzivitás a főként negatív érzelmek alapján történő döntést és megoldást, a negatív érzelmek kifejezését mutatja (pl. „Ideges vagyok problémamegoldás közben.”). Az elkerülés a helyzet megszakítását, a helyzetből való kilépést fejezi ki (pl. „Húzom-halasztom a problémák megoldását.”). A megoldási folyamat befejeződhet, ha a kimenetel pozitív, illetve amennyiben negatív kimenetel esetén az egyén feladja a probléma megoldását, azonban ilyen esetben újra is kezdheti azt. Chang és munkatársai (2004) szerint a racionális stílus gyakrabban jár pozitív következménnyel, mint az impulzív és az elkerülö, ugyanakkor e három alapján nem csoportosíthatók az emberek, hiszen szerintük nem elkülönülö, egymástól független stílusokról van szó. Mindenki alkalmazhatja ezeket, egy-egy személynél ezek - helyzettől és a másik egyéntől függően - összekapcsolódhatnak, ugyanakkor az eddigi kutatások alapján az életkor előrehaladtával egy-egy stílus dominánssá válik minden ember esetében (Kasik, 2015).

Számos országban vizsgálták már a problémamegoldás életkori jellemzőit, változását. Kasik (2008, 2010, 2012, 2014) a szociálisprobléma-megoldás alakulását az SPSI-R (Social Problem-Solving Inventory-Revised) rövidített változatával tárta fel 8-23 évesek körében. A kérdőív önjellemzéses változata mellett szülők és pedagógusok is jellemezték a 8-18 éveseket. Az eredmények összességében azt mutatják, hogy 
a szociálisprobléma-megoldás pozitív megítélése a serdülőkor előtt inkább jellemző, mint a serdülőkorban és azt követően, és ezzel ellentétes a negatív orientáció változása. A racionalitás a serdülőkortól egyre jellemzőbb, akárcsak az impulzivitás és az elkerülés, utóbbi jelentősen nő a serdülőkor közepétől. Kasik, Guti és Gáspár (2014) kutatásából az is kiderül, hogy a családi jellemzők (családszerkezet: kivel él a gyermek, szülők iskolai végzettsége) a negatív orientáció, az impulzivitás és az elkerülés esetében nagyobb magyarázóerővel bírnak a hátrányos helyzetű serdülőknél (12, 14, 16 éveseknél), mint a nem hátrányos helyzetű kortársaiknál. Mindhárom életkorban szignifikánsan jellemzőbb a negatív orientáció és az impulzivitás a hátrányos helyzetü diákokra, illetve a 14 és a 16 éves tanulókra az elkerülés is jellemzőbb. A 16 éves nem hátrányos helyzetü tanulókra a racionalitás jellemzőbb. A hazai vizsgálatok alapján (Kasik, 2010, 2012, 2015) az anya iskolai végzettsége a negatív orientáció, az impulzivitás és az elkerülés esetében bír nagyobb magyarázóerővel, míg az apáé a pozitív orientációra és a racionalitásra hat nagyobb mértékben.

A problémamegoldás változásáról pontosabb képet adnak a hazai longitudinális vizsgálatok is. A vizsgálat során két szakaszban mérték a 12-14, illetve 14-16 éves tanulók problémamegoldását, önjellemző, szülői és pedagógusi kérdőívekkel, melyeket családi háttérkérdőív egészített ki. A két vizsgálat során a 14 évesek faktoronként elért értékei nem különböznek szignifikánsan, ezért a vizsgálatok együtt is értelmezhetővé váltak. A vizsgálatok szerint a pozitív orientáció csökkenése, a negatív orientáció, az elkerülés és a racionalitás növekedése jellemzi a diákokat a vizsgált időszakban, melynek mértéke faktoronként eltérő, és inkább jellemző a középiskolás időszakban. Az impulzivitás már a korai szakaszban is magas értéket mutat, melynek tartóssága jellemzi a mintát. A nemek szerinti eltérések esetében a fiúkra jobban jellemző a racionalitás, míg a lányokra az impulzivitás. Elkerülés tekintetében a vizsgálat szerint a lányok értek el magasabb értékeket középiskolás korban, mely különbözik a keresztmetszeti vizsgálatok eredményeitől (Kasik, 2015). Ezek az eredmények nagy hasonlóságot mutatnak a már említett németországi, problémamegoldással kapcsolatos vizsgálatok eredményeivel.

Hazai vizsgálatok a problémamegoldás szorongással kapcsolatos összefüggéseit is igyekeztek feltárni. Míg külföldi vizsgálatok inkább a felnőttek szorongásával kapcsolatos eredményekről számolnak be, addig a magyar kutatás célja ezek serdülőkori meglétének vizsgálata. Eszerint azokra a diákokra, akik magas állapotszorongási szinttel rendelkeznek, inkább jellemző a probléma negatív megközelítése és elkerülése. Ezek az eredmények is nagyban megfelelnek a felnőttekkel végzett külföldi vizsgálatok eredményeinek.

\section{Empátia}

Az empátia fogalmának leírása már ókori görög írásokban is fellelhető, azonban Európába csak az 20. század elején került be a köztudatba Lipps német pszichológus fordításaként ('Einfühlung'), aki a beleélést, a beleérzés fogalmának nyomtatékosítását emelte ki, elsősorban a müvészeti alkotások, élmények érzékelésének területén. Jelentősen a 20. században alakult, formálódott, empirikus vizsgálatoknak volt szerepe az empátia mai értelmezésének kialakulásában.

Davis (1980) szerint az empátia az adott személyben kiváltódott reakciók megfigyelése által kiváltott érzelmi, kognitív és viselkedéses mechanizmusok összessége, egy multidimenzionális konstruktum. A megfigyelő személy a kognitív empátia során megismeri és megérti a másik személy problémáit, érzéseit és indítékait, míg az érzelmi empátia során létrehozza az ehhez kapcsolódó megfelelő érzelmeket és reakciókat (Spencer, 1870; Shamay-Tsoory, 2011). Davis (1980) az általa kidolgozott kérdöívvel az empátia négy 
komponensét kívánta feltárni, szerinte ezek az empátia legfontosabb összetevői: fantázia, nézőpontfelvétel/-váltás, empátiás törődés és személyes distressz. A fantázia faktor az egyén más karakterek érzéseibe, cselekedeteibe, személyekbe, könyvekbe vagy állapotokba való beleképzelésének képességéről ad tájékoztatást. A nézőpontfelvétel/-váltás azt jellemzi, hogy hogyan képes az egyén spontán elfogadni mások nézőpontját. Az empátiás törödés arról ad tájékoztatást, miként fér hozzá az egyén mások iránti érzéseihez, hogyan képes törődni mások problémáival. A személyes distressz faktor segítségével mérhető a saját magára irányuló szorongás. Davis (1980) óta több kutató próbálta az empátia összetevőit feltárni, de a vizsgált komponensek még ma sem egyértelmüek, illetve sokszor átfedést mutatnak.

Buda (2006) szerint az empátia a nem verbális jelek felfogásának és tudatosításának képessége, mely minden emberben jelen van, de különböző mértékben nyilvánulhat meg. Látható, hogy a két megközelítés az empátia különböző területeire helyezi a hangsúlyt, így az idő előrehaladtával az empátia fogalma folyamatosan bővült. Ez a bővülés, illetve az egyes kultúrák közötti eltérések az okai annak, hogy az empátiának még a mai napig nincsen egységesen elfogadott definíciója (Buda, 2006).

Az empátia nem szerinti vizsgálata Hoffman (1977) kezdeményezési nyomán indult meg. Eisenberg és Lennon (1983) azt találta, hogy a női nemre jellemzőbb az empátia. Mestre, Samper, Frías és Tur (2009) eredményekböl kiderült, hogy az egy korosztályban lévő fiúk és lányok közül a lányok teljesítettek jobban az empátiát mérö feladatokban. 14 éves kor felett az életkor előrehaladtával a nemi különbség egyre nő az azonos korú fiúk és lányok között.

\section{Szorongás}

A szorongásra már régi latin írásos emlékekben is találhatók utalások, de az első tudományosan megalapozott pszichológiai megközelítés Freud (1920) nevéhez köthető, aki szerint a szorongás egy stresszes állapotra adott érzelmi reakció, nem azonos a félelemmel, ami egy adott objektumra vonatkozik (Oláh, 2005). Freud (1926/1990) szerint a szorongás hajlamként is megjelenhet, aminek szintje különböző az egyes emberekben, oka a folyamatos depresszió és a várható kimenetelek negatív irányú megközelítése.

Freud ezen elmélete szolgált alapul Cattell (1966) állapot- és vonásszorongásról szóló elméletének, amit később Spielberger (1972) dolgozott ki részletesen. A vonásszorongás a különböző szituációkban megjelenő, következetes reakciókat, jellemző viselkedést takarja, ami az adott egyénre jellemző tulajdonság stresszes helyzetekben. Az állapotszorongás az egyénekre és az adott szituációra jellemző, pillanatnyilag megnyilvánuló állapot, viselkedéses reakció. Azok az emberek, akikre magas vonásszorongás jellemző, veszélyesebbnek, fenyegetőbbnek éreznek bizonyos helyzeteket, mint azok, akikben ez a szint alacsonyabb, s ez magasabb állapotszorongást jelez, ami az adott helyzet által kiváltott szorongás.

Külföldi és hazai vizsgálatok (Rachman, 2004; Guti, 2014) alapján a pubertáskor nagyon fontos időszak a szorongás különböző formáinak megjelenésében. Ebben az időszakban számos pszichoszociális és biológiai változás is történik, melynek okai többek között a szexuális és az értelmi érés, illetve az érzelmi élet változása. Ezek a változások megalapozhatják és elmélyíthetik a szorongást, illetve korábbi, kisgyermekkori szorongásos emlékek felelevenedésével is járhatnak. Ezt okozhatja az iskolarendszer, illetve a korai pályaválasztás, iskolaválasztás által generált feszültség is. Batanova és Loukas (2011), valamint Guti (2014) serdülőkkel végzett kutatásai alapján magasabb állapotszorongás jellemzi a lányokat. 


\section{A problémamegoldás, az empátia és a szorongás kapcsolata serdülőkorban - korábbi vizsgálati eredmények}

A problémamegoldás, az empátia és a szorongás serdülőkori kapcsolatával igen kevés vizsgálat foglalkozik. Siu és Shek (2005) a szociálisprobléma-megoldó gondolkodás, az empátia, az érzelmi és a családi jóllét kapcsolatát vizsgálták 11-17 évesek körében. A vizsgálat során a Davis-féle empátiakérdőív egy módosított változatát alkalmazták, mely során az empátiás törődés és a nézőpont-felvétel-/váltás egy faktort (empátia) alkotott a fantázia és a személyes distressz mellett. Az eredmények alapján az empátia és a fantázia pozitív összefüggést mutat a pozitív orientációval és a racionalitással, ellenben negatív összefüggést a negatív orientációval, az impulzivitással és az elkerüléssel. Az utóbbi három faktorral pozitív a kapcsolata a személyes distressznek, míg a pozitív orientációval és a racionalitással negatív.

Batanova és Loukas (2011) a szorongás és az empátia, illetve az agresszió kapcsolatát elemezték 10 és 14 év közötti tanulók körében. Az eredményekből kiderült, hogy az agresszió és a szorongás között gyenge a kapcsolat, illetve az empátia (Davis-féle) négy faktora nem mutat egyértelmü összefüggést egyik vizsgált területtel sem. A lányokra mindkét életkorban magasabb állapotszorongás, illetve magasabb érzelmiempátia-szint jellemző.

Korábbi keresztmetszeti vizsgálatunkban (Gáspár, 2014) 12, 15 és 18 évesek körében vizsgáltuk az empátia és a problémamegoldás jellemzőit és kapcsolatát - erre a vizsgálatra épül a tanulmányban bemutatott longitudinális kutatás is. A felmérés alapján a 18 évesekre jellemzőbb a negatív orientáció, a problémához és annak megoldásához való negatív viszonyulás, illetve a megoldásba vetett hit alacsonyabb szintü, mint a 12 és a 15 évesek körében. Az elkerülés faktoron a 15 és a 18 évesek értek el hasonló és a 12 éveseknél magasabb átlagot. Ez azt jelenti, hogy a középiskolásokra jellemzőbb a problémamegoldás elkerülése, a döntés vagy a kivitelezés halogatása. Az empátia faktorai közül egyiknél sem azonosítható jelentős életkori különbség. E felmérés alapján a négy empátiaterületen hasonló jellemzőkkel bírnak a 12, a 15 és a 18 évesek. A pozitív orientációra, a megoldásba vetett pozitív hitre, a problémához és a megoldási folyamathoz való pozitív viszonyulásra az empátia faktorai közül 12 és 18 éves korban hat a nézőpontfelvétel/-váltás, az idősebbeknél kisebb mértékben magyarázza a problémamegoldáshoz füződő pozitív viszonyulást. A negatív orientációra, a megoldással kapcsolatos bizonytalanságra 15 éves korban a személyes distressz ugyancsak hatást gyakorol, akárcsak 18 éves korban. A racionalitásra 12 és 15 éves korban egyaránt a nézöpontfelvétel/-váltás gyakorol hatást. Az impulzivitás alakulásában jelentős szerepe egyik empátiafaktornak sincs. Hasonlóan, az elkerülésnél is csak a 18 éveseknél bír magyarázóerővel a nézőpontfelvétel/-váltás, a többi empátiafaktor hatása nem számottevő.

\section{Az empirikus vizsgálat jellemzői}

\section{Minta}

A tanulmányban két - egy keresztmetszeti és egy longitudinális - kutatás eredményét ismertetjük. A vizsgálatok Pest, Csongrád és Bács-Kiskun megyei általános és középiskolák (négy és öt évfolyamos) tanulóinak bevonásával történtek. A longitudinális vizsgálat 2014-ben kezdődött, 12, 15 és 18 évesek vettek részt $(\mathrm{N}=167)$, ezekkel a diákokkal - 13, 16 és 19 éves korukban - 2015-ben végeztük az ismételt mérést ( $\mathrm{N}=153$, fiúk: 40 százalék, lányok: 60 százalék). Mindegyik életkorban közel azonos a fiúk és a lányok aránya. E tanulók mellett 12, 15 és 18 évesekkel keresztmetszeti vizsgálatot is végeztünk 
nagyobb mintán ( $\mathrm{N}=525$, fiúk: 36 százalék, lányok: 64 százalék), ahol szintén hasonló mindegyik évfolyamon a nemek aránya. A családi háttérről (lakhely, családszerkezet, szülők iskolai végzettsége) szerzett adatok alapján egyik jellemző mentén sincs jelentős különbség az egyes életkori csoportok között egyik felmérésben sem.

\section{Célok és hipotézisek}

A kutatások együttes célja a szociálisprobléma-megoldás, az empátia és a szorongás életkori, nem szerinti jellemzőinek, illetve kapcsolatrendszerük feltárása volt 12-19 évesek körében. A 2015-ös keresztmetszeti felmérés során azt vizsgáltuk, mi jellemzi 12, 15 és 18 évesek problémamegoldását, empátiáját és szorongását, illetve milyen összefüggésben állnak egymással e pszichikus összetevők. A 2014-es longitudinális mérés során célunk csak a problémamegoldás és az empátia kapcsolatának feltárása volt 12, 15 és 18 évesek körében, majd egy év múlva ugyanezt vizsgáltuk ezen gyerekek egy részével (longitudinális mérés 13, 16 és 19 évesekkel). A longitudinális vizsgálatban részt vevő diákok ez alatt az egy év alatt semmilyen segítö-fejlesztő programban nem vettek részt. Mindezek mellett elemeztük azt is, hogyan befolyásolja néhány családi tényező a problémamegoldás mért területeit.

A szociálisprobléma-megoldó gondolkodás mérésére a D'Zurilla és munkatársai (2002) által kifejlesztett Social Problem-Solving Inventory-Revised (SPSI-R) adaptált változatát (Kasik, Nagy és Füzy, 2010) használtuk, amivel a szociálisprobléma-megoldó gondolkodás öt jellemzője mérhető (pozitív és negatív orientáció, racionalitás, impulzivitás, elkerülés). A problémamegoldással kapcsolatos hipotéziseket a nemzetközi és a hazai kutatások (pl. Siu és Shek, 2005; Kasik, 2014, 2015) alapján fogalmaztuk meg: (1) A 12-13 évesekre jellemzőbb a pozitív orientáció, mint az idősebbekre, akik körében jellemzőbb a negatív orientáció, valamint az elkerülés, a racionalitás és az impulzivitás, (2) ám a két középiskolai korcsoport között is feltételezhető az utóbbi három esetében eltérés (növekvő tendencia a racionalitásban és az elkerülésben), illetve (3) a fiúkra jellemzőbb a racionalitás és a pozitív orientáció, a lányokra az impulzivitás, az elkerülés és a negatív orientáció.

Az empátia mérésére a Davis (1980) által kifejlesztett Interpersonal Reactivity Index (IRI) adaptált változatát használtuk (Rózsa, é. n.), ami az empátia négy faktorának (fantázia, nézőpont-felvétel/-váltás, empátiás törődés, személyes distressz) mérésére alkalmas. Azt feltételeztük, hogy (4) a középiskolások alacsonyabb értéket érnek el a mért faktorokon, kivéve a személyes distresszt, mint az általános iskolások, illetve (5) a lányok értékei magasabbak mindegyik faktoron mindegyik életkorban. A szorongás mérésére a Spielberger (1973) által kifejlesztett State-Trait Anxiety Inventory for Children (STAI-C) mérőeszközt alkalmaztuk, ami az állapot- és a vonásszorongás mérésére alkalmas kérdöív. Azt a hipotézist fogalmaztuk meg, hogy (6) a vonásszorongás szintje mindhárom életkorban hasonló, azonban az állapotszorongás szintje magasabb a 18-19 éveseknél, valamint (7) a lányok szorongásszintje magasabb a fiúkénál mindegyik életkorban. A szociálisprobléma-megoldás és az empátia kapcsolatáról azt feltételeztük, hogy (8) a kapcsolatok száma több és azok erőssége nagyobb a 12-13 éveseknél, mint az idősebbeknél - vagyis az életkor elörehaladtával a problémamegoldás és az empátia függetlenedést mutat. A három terület kapcsolatáról a hipotézisünk az volt, hogy (9) a magas szorongással rendelkezők magas személyes distresszel bírnak, illetve mindkettő szoros kapcsolatban áll a negatív orientációval és az impulzivitással. 


\section{Eredmények \\ A 2015-ös keresztmetszeti vizsgálat eredményei - a problémamegoldás és az empátia jellemzöi, kapcsolatuk}

A 2015-ös keresztmetszeti vizsgálatban a problémamegoldás, az empátia és a szorongás jellemzőit és kapcsolatukat vizsgáltuk. A problémamegoldás esetében hasonló eredményeket kaptunk, mint a 2014-es vizsgálat során. A 18 évesekre jellemzőbb a negatív orientáció $(F=8,71 \mathrm{p}=0,03)$, valamint a 15 és a 18 évesekre az elkerülés $(\mathrm{F}=4,32 \mathrm{p}=0,001)$. A pozitív orientáció, az impulzivitás és a racionalitás hasonló mindegyik életkori csoportban, ami ellentmond Kasik (2014) vizsgálati eredményeinek, ám azokat megerősítő tendenciaszerü változás látható ezekben az eredményekben is (csökkenő pozitív orientáció, növekvő impulzivitás és racionalitás).

Az empátia négy faktora közül háromnál (nézőpontfelvétel/váltás, empátiás törődés, személyes distressz) jelentős életkori különbség mutatható ki. A nézőpontfelvétel/-váltás jellemzőbb a 18 évesekre $(\mathrm{F}=5,71 \mathrm{p}=0,004)$. Az empátiás törödés és a személyes distressz a serdülőkor végén lévőkre ugyancsak jellemzőbb (empátiás törődés: $F=5,05$ $\mathrm{p}=0,007$; személyes distressz: $\mathrm{F}=5,64 \mathrm{p}=0,004)$.

Más magyar és nemzetközi vizsgálatok tapasztalatai szerint az eredeti négy faktor helyett három faktor különül el, így mi is elvégeztük a 28 tételes kérdőív faktorelemzését (Varimax-rotáció, 1-nél nagyobb sajátérték, minimum 0,4-es faktorsúly), ami egyik életkori mintán sem eredményezte az eredeti négy faktort. A fantázia és a személyes distressz dimenziója jól elkülönült (egy-két tétel került ezekből a harmadik faktorba), ám a nézőpont-felvétel/-váltás és az empátiás törődés egy faktort alkottak. A módosított faktorokkal végzett elemzés eredményei eltérnek az eredeti struktúra alapján kapott eredményektől. Az összevont faktor esetében szignifikáns a különbség az életkori csoportok között: a nézőpontfelvétel/-váltás és az empátiás törődés inkább jellemzi a 18 éveseket, mint a 12 és 15 éveseket $(\mathrm{F}=3,28 \mathrm{p}=0,03)$. A fantázia és a személyes distressz esetében a 12 évesek élesen elkülönülnek a középiskolásoktól (fantázia: $F=2,57 \mathrm{p}=0,002$; személyes distressz: $\mathrm{F}=4,34 \mathrm{p}=0,001$ ).

A lányok és a fiúk értékei között több esetben jelentős a különbség (minden esetben $\mathrm{p}<0,05$ ), ám figyelembe kell venni, hogy a lányok aránya jelentősen nagyobb volt, mint a fiúké (sorrendben 64 és 36 százalék). A 12 éves lányokra jellemzőbb a nézőpontfelvétel/-váltás $(t=2,34)$, a 15 éves lányokra a fantázia $(t=3,02)$ és a vonásszorongás $(t=3,22)$. A 18 évesek körében mindkét szorongásfaktoron (vonásszorongás: $t=2,45$; állapotszorongás: $t=3,01$ ) és az empátia valamennyi faktorán (fantázia: $t=2,45$; nézőpontfelvétel/-váltás: $\mathrm{t}=3,12$; empátiás törődés: $\mathrm{t}=2,44$, személyes distressz: $\mathrm{t}=2,56$ ) magasabb értéket értek el a lányok, illetve a racionalitás faktoron a fiúk $(\mathrm{t}=2,79)$.

\section{A problémamegoldás, az empátia és a szorongás kapcsolatrendszere a 2015-ben végzett keresztmetszeti vizsgálat alapján}

A problémamegoldás, az empátia és a szorongás kapcsolatát regresszióelemzéssel vizsgáltuk életkoronként (1. táblázat). Függő változónak a szociálisprobléma-megoldás faktorait, független változónak az empátia három faktorát, a szorongás faktorait, illetve a családi háttérrel kapcsolatos háttérjellemzőket vontuk be. A regressziós egyenesre való illeszkedést kifejező Goodness-of-fit érték minden életkori mintánál 0,69 vagy e feletti. 
Gáspár Csaba - Kasik László: A szociálisprobléma-megoldás, az empátia és a szorongás kapcsolata serdülök körében 1. táblázat. A regresszióelemzés eredményei $\left(r^{*}, R^{2}\right)$

\begin{tabular}{|c|c|c|c|c|c|c|c|c|c|c|c|c|c|c|c|}
\hline \multirow{3}{*}{$\begin{array}{c}\text { Független } \\
\text { változók/ } \\
R 2\end{array}$} & \multicolumn{5}{|c|}{12 évesek } & \multicolumn{5}{|c|}{15 évesek } & \multicolumn{5}{|c|}{18 évesek } \\
\hline & \multicolumn{5}{|c|}{ Függő változók } & \multicolumn{5}{|c|}{ Függő változók } & \multicolumn{5}{|c|}{ Függő változók } \\
\hline & $P O$ & $N O$ & $R$ & $I$ & $E$ & $P O$ & $N O$ & $R$ & $I$ & $E$ & $P O$ & $N O$ & $R$ & $I$ & $E$ \\
\hline Fantázia & n.s. & n.s. & n.s. & n.s. & n.s. & n.s. & 0,03 & n.s. & n.s. & n.s. & n.s. & 0,05 & n.s. & n.s. & n.s. \\
\hline $\begin{array}{l}\text { Nézőpont- } \\
\text { felvétel/- } \\
\text { váltás - } \\
\text { Empátiás } \\
\text { törődés }\end{array}$ & 0,01 & n.s. & 0,09 & n.s. & n.s. & n.s. & n.s. & 0,08 & n.s. & n.s. & 0,07 & n.s. & 0,10 & n.s. & n.s. \\
\hline $\begin{array}{l}\text { Személyes } \\
\text { distressz }\end{array}$ & n.s. & 0,15 & n.s. & n.s. & 0,1 & n.s. & 0,19 & n.s. & n.s. & 0,07 & 0,04 & 0,09 & n.s. & n.s. & 0,08 \\
\hline $\begin{array}{l}\text { Vonás- } \\
\text { szorongás }\end{array}$ & n.s. & 0,20 & n.s. & n.s. & 0,03 & n.s. & 0,11 & n.s. & 0,06 & 0,04 & n.s. & 0,06 & n.s. & 0.04 & n.s. \\
\hline $\begin{array}{l}\text { Állapot- } \\
\text { szorongás }\end{array}$ & n.s. & n.s. & n.s. & 0,02 & 0,02 & n.s. & n.s. & n.s. & 0,12 & n.s. & n.s. & n.s. & 0,04 & 0,11 & n.s. \\
\hline $\begin{array}{l}\text { Anya vég- } \\
\text { zettsége }\end{array}$ & n.s. & n.s. & n.s. & n.s. & n.s. & n.s. & 0,12 & n.s. & n.s. & 0,03 & n.s. & 0,13 & n.s. & 0,02 & 0,07 \\
\hline $\begin{array}{l}\text { Apa vég- } \\
\text { zettsége }\end{array}$ & n.s. & n.s. & n.s. & n.s. & n.s. & 0,11 & n.s. & n.s. & n.s. & n.s. & 0,12 & n.s. & n.s. & n.s. & n.s. \\
\hline Kivel él & n.s. & n.s. & n.s. & n.s. & n.s. & 0,01 & n.s. & n.s. & n.s. & n.s. & n.s. & n.s. & n.s. & n.s. & n.s. \\
\hline R2 (\%) & 2,1 & 32,8 & 12,1 & 2,1 & 8,1 & 15,5 & 43,3 & 12,6 & 19,8 & 15,7 & 24,8 & 34,1 & 13,4 & 14,6 & 18,7 \\
\hline
\end{tabular}

Megjegyzés: $P O=$ Pozitív orientáció, $N O=$ Negativ orientáció, $R=$ Racionalitás, $I=I m p u l z i v i t a ́ s, E=$ Elkerülés; minden esetben $p<0,05 ;$ n.s. $=$ nem szignifikáns

A regresszióelemzés adatai (1. táblázat) alapján a fantázia a negatív orientációt kismértékben magyarázza, más problémamegoldás-faktorra nem hat. Az összevont empátiafaktor hatással van mindegyik életkorban a pozitív orientációra és a racionalitásra, amit korábbi vizsgálatunk is bizonyított. Ugyancsak ismert kapcsolatot mutat a személyes distressz a negatív orientációval és az elkerüléssel, hatása ezekre azonos mértékü. A vonásszorongás a negatív orientációt és az impulzivitást, az állapotszorongás az impulzivitást magyarázza mindegyik életkorban. Az idősebbeknél az anya iskolai végzettsége a negatív orientációra, az impulzivitásra és az elkerülésre hat, valamint az apai végzettség a pozitív orientációra. A családszerkezet hatása - szemben a korábbi kutatások adataival - ezen a mintán nem jelentős.

\section{A longitudinális vizsgálat eredményei - életkori és nem szerinti változások a problémamegoldás és az empátia faktorai mentén}

A 2. táblázatban az egymintás t-próba eredményeit tüntettük fel életkori csoportonként. Azt elemeztük, történt-e változás az adott életkori almintán egy év alatt (2014 és 2015 között). 
2. táblázat. A szociálisprobléma-megoldás és az empátia változása

\begin{tabular}{|c|c|c|c|c|c|c|c|c|c|}
\hline \multirow{2}{*}{ Faktor } & 12 & $\rightarrow 13$ & \multirow{2}{*}{$t$} & 15 & $\rightarrow 16$ & & 18 & $\rightarrow 19$ & \multirow{2}{*}{$t$} \\
\hline & $\begin{array}{c}\text { Átlag } \\
\text { (szórás) }\end{array}$ & $\begin{array}{c}\text { Átlag } \\
\text { (szórás) }\end{array}$ & & $\begin{array}{c}\text { Átlag } \\
\text { (szórás) }\end{array}$ & $\begin{array}{c}\text { Átlag } \\
\text { (szórás) }\end{array}$ & & $\begin{array}{c}\text { Átlag } \\
\text { (szórás) }\end{array}$ & $\begin{array}{c}\text { Átlag } \\
\text { (szórás) }\end{array}$ & \\
\hline $\begin{array}{l}\text { Pozitív } \\
\text { orientáció }\end{array}$ & $\begin{array}{c}3,37 \\
(0,55)\end{array}$ & $\begin{array}{c}2,97 \\
(0,42)\end{array}$ & n.s. & $\begin{array}{c}3,35 \\
(0,50)\end{array}$ & $\begin{array}{c}2,89 \\
(0,65)\end{array}$ & 3,99 & $\begin{array}{c}2,79 \\
(0,43)\end{array}$ & $\begin{array}{c}3,01 \\
(0,55)\end{array}$ & n.s. \\
\hline $\begin{array}{l}\text { Negatív } \\
\text { orientáció }\end{array}$ & $\begin{array}{c}2,17 \\
(0,53)\end{array}$ & $\begin{array}{c}3,03 \\
(0,73)\end{array}$ & 6,89 & $\begin{array}{c}3,06 \\
(0,47)\end{array}$ & $\begin{array}{c}3,13 \\
(0,83)\end{array}$ & n.s. & $\begin{array}{c}3,13 \\
(0,34)\end{array}$ & $\begin{array}{c}3,43 \\
(0,73)\end{array}$ & 2,63 \\
\hline Racionalitás & $\begin{array}{c}3,18 \\
(0,66)\end{array}$ & $\begin{array}{c}3,73 \\
(0,76)\end{array}$ & 4,04 & $\begin{array}{c}2,94 \\
(0,67)\end{array}$ & $\begin{array}{c}3,49 \\
(0,80)\end{array}$ & 4,83 & $\begin{array}{c}3,02 \\
(0,51)\end{array}$ & $\begin{array}{c}3,71 \\
(0,70)\end{array}$ & 6,06 \\
\hline Impulzivitás & $\begin{array}{c}2,68 \\
(0,52)\end{array}$ & $\begin{array}{c}2,63 \\
(0,62)\end{array}$ & n.s. & $\begin{array}{c}2,60 \\
(0,50)\end{array}$ & $\begin{array}{c}2,78 \\
(0,78)\end{array}$ & n.s. & $\begin{array}{c}2,68 \\
(0,50)\end{array}$ & $\begin{array}{c}2,75 \\
(0,60)\end{array}$ & n.s. \\
\hline Elkerülés & $\begin{array}{c}2,09 \\
(0,62)\end{array}$ & $\begin{array}{c}2,72 \\
(0,84)\end{array}$ & 5,78 & $\begin{array}{c}2,65 \\
(0,77)\end{array}$ & $\begin{array}{c}2,89 \\
(0,62)\end{array}$ & n.s. & $\begin{array}{c}2,85 \\
(0,61)\end{array}$ & $\begin{array}{c}2,92 \\
(0,63)\end{array}$ & n.s. \\
\hline Fantázia & $\begin{array}{c}3,30 \\
(0,48)\end{array}$ & $\begin{array}{c}2,95 \\
(0,73)\end{array}$ & 3,05 & $\begin{array}{c}3,32 \\
(0,43)\end{array}$ & $\begin{array}{c}2,94 \\
(0,67)\end{array}$ & n.s. & $\begin{array}{c}3,31 \\
(0,42)\end{array}$ & $\begin{array}{c}2,93 \\
(0,74)\end{array}$ & n.s. \\
\hline $\begin{array}{l}\text { Nézőpont- } \\
\text { felvétel/- } \\
\text { váltás }\end{array}$ & $\begin{array}{c}2,49 \\
(0,53)\end{array}$ & $\begin{array}{c}2,95 \\
(0,60)\end{array}$ & 4,13 & $\begin{array}{c}2,54 \\
(0,38)\end{array}$ & $\begin{array}{c}2,80 \\
(0,51)\end{array}$ & 4,23 & $\begin{array}{c}2,68 \\
(0,39)\end{array}$ & $\begin{array}{c}3,07 \\
(0,62)\end{array}$ & 2,90 \\
\hline $\begin{array}{l}\text { Empátiás } \\
\text { törődés }\end{array}$ & $\begin{array}{c}2,83 \\
(0,51)\end{array}$ & $\begin{array}{c}2,80 \\
(0,34)\end{array}$ & n.s. & $\begin{array}{c}2,77 \\
(0,38)\end{array}$ & $\begin{array}{c}2,93 \\
(0,50)\end{array}$ & n.s. & $\begin{array}{c}2,85 \\
(0,45)\end{array}$ & $\begin{array}{c}3,14 \\
(0,93) \\
\end{array}$ & n.s. \\
\hline $\begin{array}{l}\text { Személyes } \\
\text { distressz }\end{array}$ & $\begin{array}{c}2,95 \\
(0,40)\end{array}$ & $\begin{array}{c}2,52 \\
(0,50)\end{array}$ & 4,11 & $\begin{array}{c}3,03 \\
(0,43)\end{array}$ & $\begin{array}{c}2,48 \\
(0,60)\end{array}$ & 3,78 & $\begin{array}{c}3,13 \\
(0,46)\end{array}$ & $\begin{array}{c}2,63 \\
(0,69)\end{array}$ & n.s. \\
\hline
\end{tabular}

Megjegyzés: szignifikáns különbség esetében $p<0,05$

Az eredmények alapján az impulzivitás kivételével minden faktor értéke szignifikánsan változott a 2014-es méréshez képest. A pozitív orientáció és a racionalitás értékei nőttek, míg a negatív orientáció és az elkerülés értékei csökkentek. Az empátia esetében minden faktornál szignifikáns a különbség a két mérés eredményei között. A fantázia és a személyes distressz értékei csökkentek, a nézőpontfelvétel/-váltás és az empátiás törődés értékei nőttek.

Elemeztük a változást külön a fiúk és külön a lányok körében is. A fiúknál nincs egyetlen faktor esetében sem szignifikáns változás, míg a lányokra mindegyik korcsoportban jellemzőbb a negatív orientáció $(12 \rightarrow 13: t=6,55 ; 15 \rightarrow 16: t=5,12 ; 18 \rightarrow 19: t=2,10)$ és a fantázia $(1213: \mathrm{t}=3,22 ; 15 \rightarrow 16: \mathrm{t}=3,21 ; 18 \rightarrow 19: \mathrm{t}=2,89-$ minden esetben $\mathrm{p}<0,05)$.

\section{Összegzés}

A bemutatott keresztmetszeti és longitudinális felmérések célja a szociálisprobléma-megoldás, az empátia és a szorongás jellemzőinek és kapcsolatuk feltárása volt. Az életkori mintákat a külföldi (pl. Siu és Shek, 2005; Mestre, Samper, Frías és Tur, 2009) és a hazai kutatások (Kasik, 2010, 2012, 2014, 2015) eredményei alapján választottuk ki; a felmérést nemzetközileg ismert és gyakran alkalmazott méröeszközök magyar változatával végeztük.

A keresztmetszeti vizsgálat alapján a negatív orientáció a 12-13 éveseknél idősebbekre jellemzőbb, amivel ellentétes a pozitív orientáció változása - mindezt alátámasztották a longitudinális vizsgálat eredményei. Már a serdülőkor elején igen jellemző a impulzivitás, illetve növekvő tendenciát mutat az elkerülés és a racionalitás. Az empátia 
A keresztmetszeti vizsgálat alapján a negatív orientáció a 12-13 éveseknél idósebbekre jellemzóbb, amivel ellentétes a pozitív orientáció változása mindezt alátámasztották a longitudinális vizsgálat eredményei. Már a serdülókor elején igen jellemzó a impulzivitás, illetve növekvố tendenciát mutat az elkerülés és a racionalitás. Az empátia mindegyik faktora ugyancsak fokozatosan nó, azonban az állapot-és a vonásszorongás alapján nincs jelentốs különbség a vizsgált diákok között. A lányok magasabb értéket értek el a negatív orientáció és az impulzivitás faktoron, illetve az empátia összes mért összetevóje, valamint a vonásszorongás jellemzóbb rájuk, mint a fiúkra. mindegyik faktora ugyancsak fokozatosan nő, azonban az állapot- és a vonásszorongás alapján nincs jelentős különbség a vizsgált diákok között. A lányok magasabb értéket értek el a negatív orientáció és az impulzivitás faktoron, illetve az empátia összes mért összetevője, valamint a vonásszorongás jellemzőbb rájuk, mint a fiúkra.

A vizsgált összetevők közötti jelentős összefüggések az életkorral fokozatosan erősödnek: a pozitív orientáció és a racionalitás egyaránt a nézőpontfelvétel/-váltással áll pozitívkapcsolatban; a negatív orientáció és az elkerülés, illetve az impulzivitás és a személyes distressz mutat jelentős pozitív összefüggést. A negatív orientációra hatást gyakorol mindegyik korcsoportban a vonásszorongás.

Az eredmények jelentős része megegyezik külföldi és korábbi hazai kutatások adataival. A jövőben fontos lesz az önjellemzés mellett a szülők és a pedagógusok saját maguk megítélését is kérni, ezeket összevetni a diákok önjellemzésével, ami képet adhat arról, milyen mintát látnak szüleiktől és pedagógusaiktól, ez a minta milyen mértékben befolyásolja problémamegoldásukat. Mindez alapjául szolgálhat egy segítö-fejlesztőprogram kidolgozásának.

\section{Irodalom}

Allport, G. W.(2000): A személyiség alakulása. Kairosz Kiadó, Szentendre.

Buda Béla (2006): Empátia. A beleélés lélektana. Urbis Könyvkiadó, Budapest.

Batanova, M. D. és Loukas, A. (2011): Social anxiety and aggression in early adolescents: Examining the moderating roles of empathic concern and perspective taking. Journal of Youth and Adolescence, 40. 1534-1543. DOI: 10.1007/s10964-011-9634-X

Cattell, R. B. (1966): Patterns of change: Measurement in relation to state-dimension, trait change, lability, and process concepts. In: Cattell, R. B. (szerk.): Handbook of Multivariate Experimental Psychology. Rand McNally, Chicago.

Chang, E. C., D’Zurilla, T. J. és Sanna, L. J. (2004): Social problem solving. Theory, research, and trai- ning. American Psychological Association, Washington, DC. DOI: 10.1037/10805-000

Channon, S. és Crawford, S. (2010): Mentalising and social problem-solving after brain injury. Neuropsychology Rehabilitation, 20. 5. sz. 739-759. DOI: 10.1080/09602011003794583

Coy, K., Speltz, M. L., DeKlyen, M. és Jones, K. (2001): Social-cognitive processes in preschool boys with and without oppositional defiant disorder. Journal of Abnormal Child Psychology, 29. 2. sz. $107-$ 119.

Davis, M. H. (1980): A multidimensional approach to individual differences in empathy. JSAS Catalog Select Documents Psychology, 10. 85.

Davis, M. H. (1983). Measuring individual differences in empathy: Evidence for a multidimensional 
approach. Journal of Personality and Social Psychology, 44. 113-126. DOI: 10.1037//0022-3514.44.1.113

Dereli, E., Angin, E. és Karakus, Ö. (2012): Factors that affect the problem solving skills of preschool teacher candidates: academic achievement and types of anxiety. International Journal of Human Sciences, 9. 2. sz. 731-742

D’Zurilla, T. J. és Goldfried, M. R. (1971): Problem solving and behavior modification. Journal of Abnormal Psychology, 78. 1. sz. 107-126. DOI: 10.1037/ h0031360

D’Zurilla, T. J. és Nezu, A. (1990): Development and preliminary evaluation of the Social Problem-Solving Inventory (SPSI). Journal of Consulting and Clinical Psychology, 2. 156-163. DOI: 10.1037/10403590.2.2.156

D'Zurilla, T. J., Maydeu-Olivares, A. és Kant, G. L. (1998): Age and gender differences in social problem solving in college students, middle age, and elderly adults. Personality and Individual Differences, 25. 241-252. DOI: 10.1016/s0191-8869(98)00029-4

D’Zurilla, T. J., Nezu, A. és Maydeu-Olivares, A. (2002): Social Problem-Solving Inventory-Revised (SPSI-R): Technical Manual. Multi-Health Systems, North Tonawanda, NewYork. DOI: 10.1037/t05068000

Eisenberg, N. és Lennon, R. (1983): Sex differences in empathy and related capacities. Psychological Bulletin, 94. 1. sz. 100-131. DOI: 10.1037//00332909.94.1.100

Freud, S. (2010): Anxiety. (25. lecture) In: uő: A General Introduction to Psychoanalysis. Boni and Liveright/ Bartleby.com, New York.

Freud, S. (1990): Inhibitions, symptoms and anxiety. Standard edition. W. W. Norton \& Company, New York.

Guti Kornél (2014): A szorongás és az empátia kapcsolata 14 és 18 évesek körében. Szakdolgozat. SZTE BTK Pszichológiai Intézet, Szeged.

Hoffman, M. L. (1977): Sex differences in empathy and related behaviors. Psychological Bulletin, 54. 4. sz. 712-722. DOI: 10.1037//0033-2909.84.4.712

Kasik László (2008[2009]): A szociálisprobléma-megoldó képesség jellemzői és vizsgálata. Új Pedagógiai Szemle, 58. 8-9. sz. 15-27.

Kasik László (2010): A szociálisprobléma-megoldó gondolkodás és képesség jellemzői. In: Zsolnai Anikó és Kasik László (szerk.): A szociális kompetencia fejlesztésének elméleti és gyakorlati alapjai. Nemzeti Tankönyvkiadó, Budapest. 97-114.

Kasik László (2012): A szociálisprobléma-megoldó és az induktív gondolkodás kapcsolata 8, 12, 15 és 18 évesek körében. Magyar Pedagógia, 112. 4. sz. 243 263.

Kasik László, Guti Kornél és Gáspár Csaba (2014). Hátrányos és nem hátrányos helyzetü diákok szociálisprobléma-megoldó gondolkodása. Magyar Pedagógia, 114. 1. sz. 49-63.

Kasik László (2014): Development of social problem solving - A longitudinal study (2009-2011) in a Hungarian context. European Journal of Developmental Psychology. 2014. 12.01-i megtekintés, http://www. $\mathrm{t}$ a $\mathrm{n}$ d f o n 1 i n e . c o m / d o i / abs/10.1080/17405629.2014.969702?journalCode= p ed p 20 \#. V H y IR D G G - m E . D O I : 10.1080/17405629.2014.969702

Kasik László (2015): Személyközi problémák és megoldásuk. Gondolat Kiadó, Budapest.

Maccoby, E. E. és Jacklin, C. N. (1974): The psychology of sex differences. Stanford University Press, Palo Alto, CA.

Mestre, M. V., Samper, P., Frías, M. D. és Tur, A. M. (2009): Are women more empathetic than men? A longitudinal study in adolescence. The Spanish Journal of Psychology, 12. 1. sz. 76-83. DOI: $10.1017 / \mathrm{s} 1138741600001499$

Mott, P. és Krane, A. (2006): Interpersonal cognitive problem-solving and childhood social competence. Cognitive Therapy and Research, 18. 127-141. DOI: 10.1007/bf02357220

Oláh, A. (2005): Anxiety, Coping, and Flow. Empirical studies in interactional perspective. Trefort Kiadó, Budapest.

Rachman, S. (2004): Anxiety. (second edition) PsychologyPress, East Sussex.

Siu, A. M. H. és Shek, D. T. L. (2005): Relations between Social Problem Solving and Indicators of Interpersonal and Family Well-Being among Chinese Adolescents in Hong Kong. Social Indicators Research Series 71. 1/3. In: Shek, D. T. L., Chan, Y. K. és Lee, P. S. N. (szerk.): Quality of Life in the Global Context: A Chinese Response. 517-539. DOI: 10.1007/1-4020-3602-7_1

Shamay-Tsoory, S. G. (2011): The neural bases for empathy. Neuroscientist, 17. 1. sz. 18-24. DOI: $10.1177 / 1073858410379268$

Spielberger, C. D. (1972): Anxiety as an emotional state. In: Spielberger, C. D. (szerk.): Anxiety: Current trends in theory and research: I. Academic Press, New York. DOI: 10.1016/b978-0-12-6574012.50008-3

Spielberger, C. D., Edwards, C. D., Montuori, J. és Lushene, R (1973): State-Trait Anxiety Inventory for Children. Consulting Psychologist Press, Palo Alto, CA. DOI: $10.1037 / \mathrm{t} 06497-000$ 